\title{
Frontiers in renal and epithelial physiology - grand challenges
}

\author{
Douglas C. Eaton* \\ Department of Physiology, Center for Cell and Molecular Signaling, Emory University School of Medicine, Atlanta, GA, USA \\ *Correspondence: deaton@emory.edu
}

\section{INTRODUCTION}

The kidneys are one of two organ systems (the other being the lungs) that had to undergo major evolutionary changes to allow vertebrates to survive in a terrestrial environment. As Homer Smith pointed out almost 60 years ago (Weder, 2007) from the perspective of evolution, the kidneys of vertebrates evolved to control blood volume, and, thereby, control blood pressure (BP) in an environment where water and salt ingestion were sporadic and generally uncoupled from one another. In ancestral marine teleosts, the primary requirement of their kidneys was to excrete a large volume of nutrient-free, isotonic urine with an electrolyte composition similar to blood. This function remains as the current day primary function of the proximal convoluted tubule in all vertebrates. As fish colonized fresh water, the requirement to prevent dilution of blood electrolytes required the kidneys to conserve salt and led to the evolution of the proximal straight tubule and the distal convoluted tubule's ability to reabsorb salt with little water reabsorption. The advent of terrestrial vertebrates required conservation of both salt and water and mechanisms for the separate control of salt and water balance since salt and water were often ingested separately. These requirements in mammals promoted the evolution of the loop of Henle, the collecting duct system, and renal medulla.

In this evolutionary context, the kidney represents one of the major locations in which the inside world of the body communicates with the external world. At the center of all this communication is the nephron, the functional unit of the kidney; and within the nephron the barrier across which communication occurs are the various epithelial cell types and tissues within the nephron. Epithelial tissues are certainly not restricted to the kidney, but the kidney represents a classic example of the function of epithelial tissue. The initial step in renal function is the separation of a very large volume (180 L/day) of blood ultrafiltrate that is delivered to the lumen of the nephrons. The epithelial tissue of the nephrons forms a barrier between this filtrate and the interstitial space of the body. The epithelium is a selective barrier promoting conservation (reabsorption) of materials in the nephron lumen that are necessary to the body while preventing reabsorption or even promoting secretion of materials that are not needed or even harmful to the body. In the process, the volume of fluid in the lumen of all the nephrons is reduced from about $180 \mathrm{~L}$ of fluid to about $1 \mathrm{~L}$ of fluid/day with a composition of electrolytes and nonelectrolytes that exactly matches the generally poorly controlled input from other parts of the body. Thus, the kidney maintains the homeostatic balance critical for all organisms, but particularly terrestrial vertebrates. It is in the pathologies of mechanisms for maintaining this homeostatic balance that the grand challenges for renal physiology lay. But, because of the central role of epithelial tissue in renal physiology, the grand challenges will include understanding the mechanisms by which epithelial tissues can act as a selective barrier between the blood and the outside world and how this barrier can go awry. In considering the pathologies that lead to grand challenges in renal physiology, it is useful to keep the kidney's evolution in mind because evolution provides a rationale for renal regulatory and transport mechanisms which otherwise might appear to be a willy nilly collection of transporters and hormonal control mechanisms with little systematic integration.

\section{THE CHALLENGE OF UNDERSTANDING HYPERTENSION}

Hypertension is a chronic increase of $\mathrm{BP}$ to levels above normal. By definition, an individual has hypertension when his or her BP is at or above $140 / 90 \mathrm{mmHg}$. High $\mathrm{BP}$ is a major risk factor for heart disease and stroke, end-stage renal disease, and peripheral vascular disease and is a chief contributor to adult disability (National Heart Lung and Blood Institute, 2011). Approximately one in four adults in the United States has hypertension (Kearney et al., 2004). Although effective therapy has been available for more than 50 years
(Kearney et al., 2005), most persons with hypertension do not have their BP under control (Chobanian et al., 2003). During 1999-2002, the age-adjusted prevalence of hypertension in the study population was $28.6 \%$. The prevalence of hypertension increased with age and was higher among women than men. Hypertension predisposes individuals to develop cardiovascular disease, renal disease, and cerebral vascular injury that was associated with the deaths of 44,619 Americans in 2000.

\section{HYPERTENSION: A DISEASE OF ABNORMAL SODIUM BALANCE}

The association of salt with hypertension has been suspected for more than 4,500 years since the Chinese suggested that salt "hardens" the pulse (Ruskin, 1956). Hypertension is often considered a disease of civilization since the genes producing hypertension or at least a pre-disposition to hypertension are now maladaptive. Presumably the genes provided selective advantage if salt was quite scarce; that is, they are "thrifty genes" (Neel, 1962; Gleiberman, 2001). Natural selection shapes organisms to function within a particular set of environmental conditions, but environments change and in the case of thrifty genes the modern environment with readily available salt promotes the development of diseases like hypertension (Wilson, 2011b). The average American diet contains about $10 \mathrm{~g}$ of salt/day, but the ingested amount of salt can vary enormously depending upon the dietary composition. Despite these large daily variations in salt intake, normal values of plasma sodium deviate very little from the normal range of 135-145 mmol/L. Therefore, under normal circumstances, the input must be critically balanced by an output that is exactly equal to the input. While there is some sodium output in sweat and feces; the output in sweat is incidental to maintaining thermal balance and the output in feces under any normal physiological circumstance is generally small. The obvious point for control of total body sodium is variable excretion by the kidneys. Urinary sodium 
concentrations are usually in the range of $10-40 \mathrm{mmol} / \mathrm{L}$; but can range from undetectable to $150 \mathrm{mmol} / \mathrm{L}$. Thus, the kidney is the primary organ responsible for removing sodium from the body and for maintaining total body sodium balance and normal blood levels of sodium. $\mathrm{Na}^{+}$is the principal extracellular cation making up over $90 \%$ of the osmotically active solute in the body, and under normal conditions $\mathrm{Na}^{+}$content largely determines extracellular fluid (ECF) volume. Thus, $\mathrm{Na}^{+}$plays a vital role in maintaining ECF volume and therefore BP.

Hypertension must always be associated with a blood volume and total body sodium content that is too high for the physiological circumstances (Guyton, 1990a, 1991, 1992). In some cases the reason for the excess blood volume is clear. There are a large number of identifiable single genetic defects in the regulation of sodium balance that lead to either increases or decreases in BP. Despite the relatively extensive list of known defects, in many cases of hypertension, the etiology is unclear. Renin levels, angiotensin levels, and aldosterone levels, hormones that normally control salt balance and BP, are normal or even reduced, and yet, $\mathrm{BP}$ is elevated as if the set point of the control loop from sensing $\mathrm{BP}$ to sodium reabsorption is inexplicably high (Guyton, 1990b; Hall et al., 1996). There are familial propensities to develop hypertension implying some significant genetic component to the disease. However, except for the highly specific monogenetic disorders, the examination of the genetics of hypertension have suggested an involvement of a very large number of genes. At least 22 different areas of the genome have been identified in genome-wide association studies (Smith, 1953; Wilson, 2011a) and the genome sequence of the Dahl spontaneously hypertensive rat had a surprisingly large number of mutated genes (788 genes are mutated in SHR compared to the reference genome, including 60 that are deleted altogether; Atanur et al., 2010). As one might have expected based on the role of the renal epithelial tissues in hypertension, of the 788 mutated genes identified in the SHR genome, many are related to cellular functions such as ion transport and plasma membrane localization, their relationship to the causes of hypertension are unclear.

Physiology, as a discipline, is involved in the study of function and systemic integration. The results from the genetic analyses of hypertension underscores the importance of contemporary physiology. The grand challenge for renal physiologists will be to examine the protein products of the genes linked to hypertension, determine their function and how they interact with one another, and how at a systemic level they can contribute to hypertension.

\section{THE CHALLENGE OF POLYCYSTIC KIDNEY DISEASE}

Hypertension is a systemic disorder that finally is manifest as a defect in renal regulation. However, there are more specific problems affecting the renal epithelium, itself. Polycystic kidney disease (PKD) is a kidney disorder passed down through families in which many cysts form in the kidneys, causing them to become enlarged (Figure 1). PKD occurs in two forms, autosomal dominant and autosomal recessive. Autosomal dominant PKD occurs in both children and adults, but it is much more common in adults. Symptoms often do not appear until middle age. It affects nearly 1 in 1,000 Americans. The actual number may be more, because some people do not have symptoms. The autosomal recessive form of PKD appears in infancy or childhood. This form is much less common than autosomal dominant PKD, but it tends to be very serious and gets worse quickly. It can cause serious lung and liver disease, endstage kidney disease, and it usually causes death in infancy or childhood. Other than symptomatic treatment, there is no other treatment for the underlying fundamental cause of either form of the disease.
Autosomal dominant polycystic kidney disease (ADPKD) is caused by mutation of PKD1 and PKD2 genes that encode polycystin-1 and polycystin-2 proteins (Wilson, 2011b). Polycystin-1 and 2 are transmembrane proteins that apparently transduce external developmental and polarity signals to epithelial cell interior. In normal cells, the two proteins are located in several cellular locations but one of the locations is in conjunction with primary cilia. Primary cilia are involved in mechanosensation, photoreception, and chemosensation, but the mechanosensitivity appears important in PKD (Winyard and Jenkins, 2011): in the simplest model, fluid flow across the apical surface of renal cells bends the cilia and induces calcium influx, and this is perturbed in PKD. Downstream effects include changes in cell differentiation and polarity. There are many physiological abnormalities associated with PKD, but one is failure of proper epithelial differentiation and the loss of epithelial polarity (Wilson, 2011a). Epithelial cell polarity is essential for the establishment and maintenance of the normal barrier function and regulation of fluid and electrolyte by renal epithelial tissue. Epithelial cell polarization is established early during development and is controlled by specific sets of proteins that provide cues for cellular polarization. Abnormalities in these protein polarization complexes lead to a variety of diseases in different organs, one of which is PKD in which epithelial cysts develop in renal tubules because of the mislocalization of membrane proteins. The defects in the polarity of membrane protein in autosomal dominant PKD

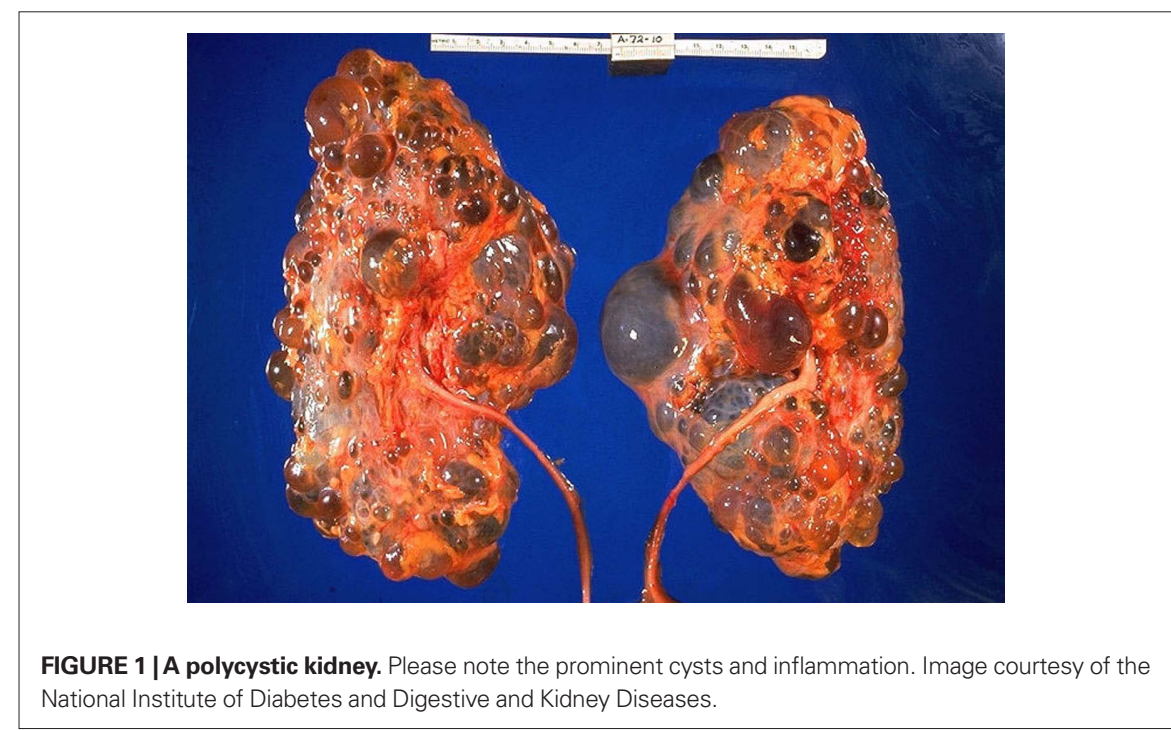


include abnormal trafficking of proteins that normally reside in the basolateral membrane to the apical membrane and vice versa. Since proper polarization of epithelial cells lining renal tubules is essential for normal kidney development and differentiation to prevent abnormal cystic dilation, the challenge is to understand the mechanisms underlying cellular polarization with the intent that understanding the mechanism would allow interventions to reverse polarity defects and, thereby, provide treatment opportunities for PKD. In addition to understanding the source of polarity, an additional challenge will be to understand how cilia fit into the other aspects of PKD physiology.

Understanding the two specific pathologies described above represent major challenges to the field of renal physiology, but they also illustrate a more general challenge to renal physiology in particular and physiology in general. With increasingly large amounts of genetic information available the challenge is to use physiological methods to link the genes to the function of the proteins they encode. This should allow translation of physiological data from the bench to the bedside.

\section{ACKNOWLEDGMENTS}

The author wishes to thank Drs. He-Ping Ma and Jeff Sands for useful discussions. This article was supported by National Institutes of Health grant NIH R37 DK037963 (to Douglas C. Eaton).

\section{REFERENCES}

Atanur, S. S., Birol, I., Guryev, V., Hirst, M., Hummel, O., Morrissey, C., Behmoaras, J., Fernandez-Suarez, X. M., Johnson, M. D., McLaren, W. M., Patone, G., Petretto, E., Plessy, C., Rockland, K. S., Rockland, C., Saar, K., Zhao, Y., Carninci, P., Flicek, P., Kurtz, T., Cuppen, E., Pravenec, M., Hubner, N., Jones, S. J., Birney, E., and Aitman, T. J. (2010). The genome sequence of the spontaneously hypertensive rat: analysis and functional significance. Genome Res. 20, 791-803.

Chobanian, A.V., Bakris, G. L., Black, H. R., Cushman, W. C., Green, L. A., Izzo, J. L. Jr., Jones, D. W., Materson, B. J., Oparil, S., Wright, J.T. Jr., and Roccella, E. J. (2003). The seventh report of the joint national committee on prevention, detection, evaluation, and treatment of high blood pressure: the JNC 7 report. J. Am. Med. Assoc. 289, 2560-2572.

Gleiberman, L. (2001). Salt, hypertension, evolution. Psychosom. Med. 63, 325-327.

Guyton, A. C. (1990a). Long-term arterial pressure control: an analysis from animal experiments and computer and graphic models. Am. J. Physiol. 259, R865-R877.
Guyton, A. C. (1990b). Renal function curves and control of body fluids and arterial pressure. Acta Physiol. Scand. Suppl. 591, 107-113.

Guyton, A. C. (1991). Blood pressure control - special role of the kidneys and body fluids. Science 252, 1813-1816.

Guyton, A. C. (1992). Kidneys and fluids in pressure regulation. Small volume but large pressure changes. Hypertension 19, I2-I8.

Hall, J. E., Guyton, A. C., and Brands, M. W. (1996). Pressure-volume regulation in hypertension. Kidney Int. Suppl. 55, S35-S41.

Kearney, P. M., Whelton, M., Reynolds, K., Muntner, P., Whelton, P. K., and He, J. (2005). Global burden of hypertension: analysis of worldwide data. Lancet 365 , 217-223.

Kearney, P. M., Whelton, M., Reynolds, K., Whelton, P. K., and He, J. (2004). Worldwide prevalence of hypertension: a systematic review. J. Hypertens. 22, 11-19.

National Heart Lung and Blood Institute. (2011). Who is at risk for high blood pressure? Available at: www. NHLBI.NIH.gov

Neel, J. V. (1962). Diabetes mellitus: a "thrifty" genotype rendered detrimental by "progress"? Am. J. Hum. Genet. 14 353-362.

Ruskin, A. (1956). Classics in Arterial Hypertension. Springfield: Charles C. Thomas.

Salvi, E., Kutalik, Z., Glorioso, N., Benaglio, P., Frau, F., Kuznetsova, T., Arima, H.,Hoggart, C., Tichet,J.,Nikitin, Y. P., Conti, C., Seidlerova, J., Tikhonoff, V., StolarzSkrzypek, K., Johnson, T., Devos, N.,Zagato,L., Guarrera, S., Zaninello, R., Calabria, A., Stancanelli, B., Troffa, C., Thijs, L., Rizzi, F., Simonova, G., Lupoli, S., Argiolas, G., Braga, D., D’Alessio, M. C., Ortu, M. F., Ricceri, F., Mercurio, M., Descombes, P., Marconi, M., Chalmers, J., Harrap, S., Filipovsky, J., Bochud, M., Iacoviello, L., Ellis, J., Stanton, A. V., Laan, M., Padmanabhan, S., Dominiczak, A. F., Samani, N. J., Melander, O., Jeunemaitre, X., Manunta, P., Shabo, A., Vineis, P., Cappuccio, F. P., Caulfield, M. J., Matullo, G., Rivolta, C., Munroe, P. B., Barlassina, C., Staessen, J.A., Beckmann, J. S., and Cusi, D. (2011). Genomewide association study using a high-density single nucleotide polymorphism array and case-control design identifies a novel essential hypertension susceptibility locus in the promoter region of endothelial NO synthase. Hypertension. doi: 10.1161/HYPERTENSIONAHA.111.181990. [Epub ahead of print].

Smith, H. W. (1953). From Fish to Philosopher. Boston: Little Brown \& Company.

Wain, L. V., Verwoert, G. C., O’Reilly, P. F., Shi, G., Johnson, T., Johnson, A. D., Bochud, M., Rice, K. M., Henneman, P., Smith, A. V., Ehret, G. B., Amin, N., Larson, M. G., Mooser, V., Hadley, D., Dorr, M., Bis, J. C., Aspelund, T., Esko, T., Janssens, A. C., Zhao, J. H., Heath, S., Laan, M., Fu, J., Pistis, G., Luan, J., Arora, P., Lucas, G., Pirastu, N., Pichler, I., Jackson, A. U., Webster, R. J., Zhang, F., Peden, J. F., Schmidt, H., Tanaka, T., Campbell, H., Igl, W., Milaneschi, Y., Hottenga, J. J., Vitart, V., Chasman, D. I., Trompet, S., Bragg-Gresham, J. L., Alizadeh, B. Z., Chambers, J. C., Guo, X., Lehtimaki, T., Kuhnel, B., Lopez, L. M., Polasek, O., Boban, M., Nelson, C. P., Morrison, A. C., Pihur, V., Ganesh, S. K., Hofman, A., Kundu, S., Mattace-Raso, F. U., Rivadeneira, F., Sijbrands, E. J., Uitterlinden, A. G., Hwang, S. J., Vasan, R. S., Wang, T. J., Bergmann, S., Vollenweider, P., Waeber,
G., Laitinen, J., Pouta, A., Zitting, P., McArdle, W. L., Kroemer, H. K., Volker, U., Volzke, H., Glazer, N L., Taylor, K. D., Harris, T. B., Alavere, H., Haller, T., Keis, A., Tammesoo, M. L., Aulchenko, Y., Barroso, I., Khaw, K. T., Galan, P., Hercberg, S., Lathrop, M., Eyheramendy, S., Org, E., Sober, S., Lu, X., Nolte, I. M., Penninx, B. W., Corre, T., Masciullo, C., Sala, C., Groop, L., Voight, B. F., Melander, O., O'Donnell, C. J., Salomaa, V., d'Adamo, A. P., Fabretto, A., Faletra, F., Ulivi, S., Del Greco, M. F., Facheris, M., Collins, F. S., Bergman, R. N., Beilby, J. P., Hung, J., Musk, A. W., Mangino, M., Shin, S. Y., Soranzo, N., Watkins, H., Goel, A., Hamsten, A., Gider, P., Loitfelder, M., Zeginigg, M., Hernandez, D., Najjar, S. S., Navarro, P., Wild, S. H., Corsi, A. M., Singleton, A., de Geus, E. J., Willemsen, G., Parker, A. N., Rose, L. M., Buckley, B., Stott, D., Orru, M., Uda, M., van der Klauw, M. M., Zhang, W., Li, X., Scott, J., Chen, Y. D., Burke, G. L., Kahonen, M., Viikari, J., Doring, A., Meitinger, T., Davies, G., Starr, J. M., Emilsson, V., Plump, A., Lindeman, J. H., Hoen, P. A., Konig, I. R., Felix, J. F., Clarke, R., Hopewell, J. C., Ongen, H., Breteler, M., Debette, S., DeStefano, A. L., Fornage, M., Mitchell, G. F., Smith, N. L., Holm, H., Stefansson, K., Thorleifsson, G., Thorsteinsdottir, U., Samani, N. J., Preuss, M., Rudan, I., Hayward, C., Deary, I. J., Wichmann, H. E., Raitakari, O. T., Palmas, W., Kooner, J. S., Stolk, R. P., Jukema, J. W., Wright, A. F., Boomsma, D. I., Bandinelli, S., Gyllensten, U. B., Wilson, J. F., Ferrucci, L., Schmidt, R., Farrall, M., Spector, T. D., Palmer, L. J., Tuomilehto, J., Pfeufer, A., Gasparini, P., Siscovick, D., Altshuler, D., Loos, R. J., Toniolo, D., Snieder, H., Gieger, C., Meneton, P., Wareham, N. J., Oostra, B. A., Metspalu, A., Launer, L., Rettig, R., Strachan, D. P., Beckmann, J. S., Witteman, J. C., Erdmann, J., van Dijk, K. W., Boerwinkle, E., Boehnke, M., Ridker, P. M., Jarvelin, M. R., Chakravarti, A., Abecasis, G. R., Gudnason, V., Newton-Cheh, C., Levy, D., Munroe, P. B., Psaty, B. M., Caulfield, M. J., Rao, D. C., Tobin, M. D., Elliott, P., and van Duijn, C. M. (2011). Genomewide association study identifies six new loci influencing pulse pressure and mean arterial pressure. Nat. Genet. 43, 1005-1011.

Weder, A. B. (2007). Evolution and hypertension. Hypertension 49, 260-265.

Wilson, P. D. (2011a). Apico-basal polarity in polycystic kidney disease epithelia. Biochim. Biophys. Acta 1812, 1239-1248.

Wilson, P.D. (2011b). Molecular mechanisms of polycystic kidney disease. Biochim. Biophys. Acta 1812, 1201

Winyard, P., and Jenkins, D. (2011). Putative roles of cilia in polycystic kidney disease. Biochim. Biophys. Acta $1812,1256-1262$.

Received: 02 January 2012; accepted: 02 January 2012; published online: 16 January 2012.

Citation: Eaton DC (2012) Frontiers in renal and epithelial physiology - grand challenges. Front. Physiol. 3:2. doi: 10.3389/fphys.2012.00002

This article was submitted to Frontiers in Renal and Epithelial Physiology, a specialty of Frontiers in Physiology. Copyright () 2012 Eaton. This is an open-access article distributed under the terms of the Creative Commons Attribution Non Commercial License, which permits non-commercial use, distribution, and reproduction in other forums, provided the original authors and source are credited. 